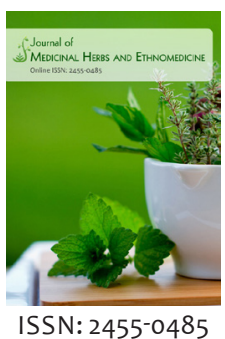

Received: September 22, 2020 Accepted: October 06, 2020 Published: October 08, 2020

*Corresponding Author: Muatasim Jan, Email: mirtawseef787@ gmail.com

\section{Indigenous medicinal usage of family Solanaceae and Polygonaceae in Uri, Baramulla, Jammu and Kashmir}

\author{
Muatasim Jan*, Tawseef Ahmad Mir, Rakesh Kumar Khare \\ Centre of Research for Ethnobotany, Govt. Model Science College, Jiwaji University, Gwalior, India-474009
}

\begin{abstract}
Kashmir Himalaya is known for it's dense and diverse vegetation. People here have gained immense knowledge regarding the use of medicinal plants for the treatment of different ailments. Present study attempts to explore and document the medicinal plants belonging to family Solanaceae and Polygonaceae used against different ailments by tribal communities of Uri, Baramulla, Jammu and Kashmir. Data was collected by using semi structured interviews and group discussions. Besides local tribal communities of Gujjar and Bakerwal, herbal healers and local knowledgeable persons were consulted during the course of study. During the study a total of 25 plants were reported with a species contribution of 10 and 15 of Solanaceae and Polygonaceae respectively. The study revealed that either whole plant or some plant parts are used as remedies against different ailments in the area.
\end{abstract}

KEYWORDS: Medicinal plants, solanaceae, polygonaceae, gujjar, bakerwal, uri, jammu and kashmir

\section{INTRODUCTION}

Plants have been playing a great role in human health care system from thousands of years and is an old age practice in Indian Himalayan region including Kashmir. This practice of treatment is relied on belief and experience of the ethnic people, which is a part of their ancestral culture and tradition [1]. The history of use of plants in traditional healthcare system can be traced back to Vedic periods about 4500-1600 B.C. The oldest book of Vedas, The Rigveda is said to be first written attempt towards the knowledge of medicinal plants for the treatment of frequently occurring diseases [2]. According to World Health Organization (WHO), medicinal plants have maintained its popularity in all the parts of the developing world and is rapidly expanding in the industrialized countries like China and USA [3,4]. Medicinal plants have gained a wide recognition in escalating faith in herbal medicine due to lesser side effects and cost effective as compared to allopathic medicines [5]. Herbal medicines are believed to support about eighty five per cent of ailments in healthcare system across the world [6,7]. According to an estimate by World Health Organization, sixty five per cent population of India depends on traditional medicines to meet their primary health care needs [8. Knowledge on the medicinal plants has been found to be one of the reliable approaches towards the development of modern drugs [9]. A properly documented and validated information on ethnomedicinal practices play a pivotal role in new scientific research [10]. The valuable knowledge associated with medicinal plants validated by scientific perceptions, may provide a novel model for sustainable development. However, traditional knowledge is threatened by unsustainable development with anthropogenic climate change [11]. Jammu and Kashmir being the part of western Himalayas is a reservoir of more than 572 different medicinal plants [12]. It harbours a great diversity of medicinal plants used in traditional health care system by tribal communities from thousands of years. Traditional medicines are the only means of healthcare in rural and remote areas [13]. Due to the luxuriant growth of high value medicinal plants in the nearby forests in the area, tribal communities of the study area still use folk medicines to a greater extent for the treatment of various ailments. But this traditional knowledge about the use of plants for the treatment of various ailments is being passed on from one generation to another in the tribal communities as a word of mouth and is on the verge of extinction in certain areas as it is not well documented [14]. Keeping in view these facts, present study was conducted to document the use of medicinal plants belonging to family Solanaceae and Polygonaceae by the tribal Gujjar and Bakerwal communities of the Uri region of Baramulla, Jammu and Kashmir.

\section{MATERIAL AND METHODS}

\section{Study Area}

Uri area of district Baramulla, Jammu and Kashmir, is located some $61 \mathrm{kms}$ form district headquarters between $34.0881^{\circ}$ $\mathrm{N}, 74.0340^{\circ} \mathrm{E}$, at an altitude of 3000-5000 $\mathrm{m}$ above sea level 


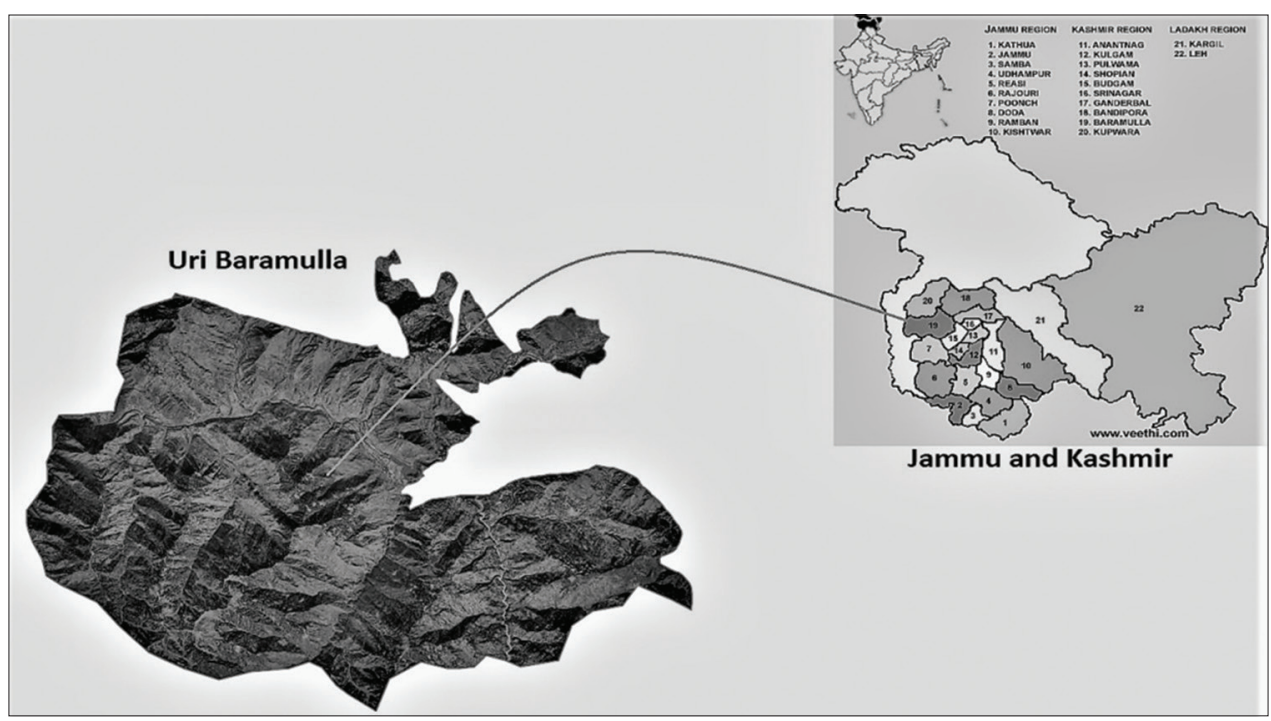

Figure 1: Map of the study area.

(Figure 1). Uri is located away from district headquarters and is sharing border with Pakistan. The temperature of the area ranges from $-7^{\circ} \mathrm{C}$ minimum in winters as it receives a good snowfall which goes to a maximum of $27^{\circ} \mathrm{C}$ in summers. The area is inhabited by people mostly of tribal communities such and Gujjar and Bakerwal. Being a border area and located at high altitude people are mostly dependent on indigenous medicine for their primary health care system. The traditional attire of the people of Uri, with complex designs and embroidery reflects the rich culture and climate of the area.

\section{Data Collection}

Present study deals with the collection of the medicinal plants of family Solanaceae and Polygonaceae and associated knowledge among the tribal communities of the Uri region of Baramulla. For the collection of medicinal plants of the respected families, field surveys were performed between April to October 2019. Data was collected by using semi structured interviews and group discussions. Besides local tribal communities of Gujjar and Bakerwal, herbal healers and local knowledgeable persons were consulted during the course of study. Data collected was recorded in field notebook. Information regarding the use of medicinal plants by local people for the treatment of various ailments was collected in local language so as to get appropriate and reliable information. Collected plant species were dried, pressed and mounted on herbarium sheets of standard size following standard herbarium techniques [15]. Identification of the plants was conducted by Flora of Kashmir [16], Flora of British India [17] and other concerned literature form Kashmir Himalaya. $[18,19]$. Data obtained from the field is presented in Table l, showing scientific name, vernacular name, family, part used, mode of administration and application of the remedy.

\section{RESULTS AND DISCUSSION}

During the course of study a total of 25 plants of family Solanaceae and Polygonaceae were reported with a species

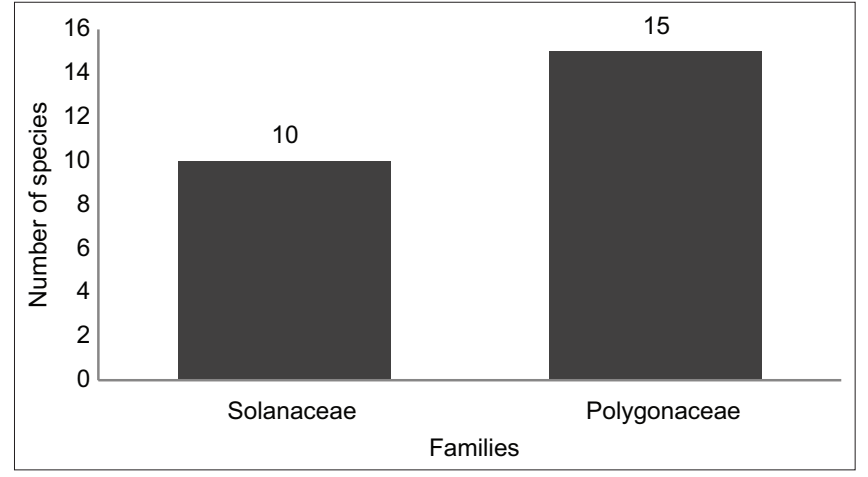

Figure 2: Species contribution of both the families.

contribution of 10 of Solanaceae and 15 of Polygonaceae (Table 1). Solanaceae was found to be the dominant family in comparison of Polygonaceae (Figure 2). The use pattern of the plants of both the families indicated that leaves, whole plant, fruits, roots, seeds, stem, rhizome and tuber are used. It was found that leaves are the most frequently used plant parts (6-species), followed by fruits and root (4-species each), whole plant, seeds and rhizome (3-species each), tuber and stem (1-species each) (Figure 3). The mode of application of the plant remedies was either oral (15-species) or topical (10-species) (Figure 4). During the study plant species were taken from wild as well as from cultivated sources.

Present study revealed the use of medicinal plants belonging to family Solanaceae and Polygonaceae for the treatment of various ailments by the tribal communities of Uri region of district Baramulla, Jammu and Kashmir. It has been estimated that $80 \%$ of the world's population is dependent on traditional medicine for their primary health care needs [20, 21]. Herbal medicines are being used because people are not able to get allopathic medicines. During the current study it was found that the knowledge regarding the use of medicinal plants of Uri area is transmitting from one generation to another orally without any written document. It was revealed that this knowledge is 
Table 1: Medicinal plants of family solanaceae and polygonaceae in Uri, Baramulla, Jammu and Kashmir

\begin{tabular}{|c|c|c|c|c|c|c|c|c|}
\hline S. No. & Botanical name/Family & $\begin{array}{l}\text { Vernacular } \\
\text { name }\end{array}$ & Flowering & Disease treated & Part used & Mode of administration & Applicat & Source \\
\hline 1 & $\begin{array}{l}\text { Atropa accuminata Royle ex } \\
\text { Lindl. } \\
\text { Solanaceae }\end{array}$ & Jal-kafal & June-July & $\begin{array}{l}\text { Boils, } \\
\text { Rheumatism }\end{array}$ & $\begin{array}{l}\text { Whole } \\
\text { plant }\end{array}$ & $\begin{array}{l}\text { Paste of plant is applied on } \\
\text { boils and to cure rheumatism. }\end{array}$ & Topical & Wild \\
\hline 2 & $\begin{array}{l}\text { Bistorta amplexicaulis } \\
\text { (D. Don) Greene } \\
\text { Polygonaceae }\end{array}$ & $\begin{array}{l}\text { Maachran- } \\
\text { chai }\end{array}$ & June-September & Cough, Cold & Root & $\begin{array}{l}\text { Decoction of root is taken to } \\
\text { cure cough and cold. }\end{array}$ & Oral & Wild \\
\hline 3 & $\begin{array}{l}\text { Bistorta vivipara L. Delarbe } \\
\text { Polygonaceae }\end{array}$ & Masloon & June-August & $\begin{array}{l}\text { Fever, Body } \\
\text { pain }\end{array}$ & Rhizome & $\begin{array}{l}\text { Powder of rhizome is taken } \\
\text { with milk to treat fever and } \\
\text { body pain. }\end{array}$ & Oral & Wild \\
\hline 4 & $\begin{array}{l}\text { Capsicum annuum L. } \\
\text { Solanaceae }\end{array}$ & Marchawangan & May-August & Dog bite & Fruit & $\begin{array}{l}\text { Fruit is rubbed on the affected } \\
\text { part in case of dog bite. }\end{array}$ & Topical & Cultivated \\
\hline 5 & $\begin{array}{l}\text { Datura stramonium L. } \\
\text { Solanaceae }\end{array}$ & Datur & June-September & Cough & Seed & $\begin{array}{l}\text { Powder of seeds is taken to } \\
\text { treat cough. }\end{array}$ & Oral & Wild \\
\hline 6 & $\begin{array}{l}\text { Fagopyrum esculentum } \\
\text { Moench. } \\
\text { Polygonaceae }\end{array}$ & Tromba & June-August & $\begin{array}{l}\text { Constipation, } \\
\text { Hypertension }\end{array}$ & Leaves & $\begin{array}{l}\text { Leaves are cooked and } \\
\text { taken to treat constipation, } \\
\text { Hypertension. }\end{array}$ & Oral & Wild \\
\hline 7 & $\begin{array}{l}\text { Hyoscyamus niger L. } \\
\text { Solanaceae }\end{array}$ & Bazar-bhang & June-July & Arthritis & Seed & $\begin{array}{l}\text { Paste of seeds is applied on } \\
\text { arthritic joints, }\end{array}$ & Topical & Wild \\
\hline 8 & $\begin{array}{l}\text { Oxyria digyna (L.) Hill } \\
\text { Polygonaceae }\end{array}$ & Lamanchu & May-August & Constipation & $\begin{array}{l}\text { Whole } \\
\text { plant }\end{array}$ & $\begin{array}{l}\text { Decoction of whole plant is } \\
\text { taken to treat constipation. }\end{array}$ & Oral & Wild \\
\hline 9 & $\begin{array}{l}\text { Persicaria hydropiper } \mathrm{L} \text {. } \\
\text { Polygonaceae }\end{array}$ & $\begin{array}{l}\text { Marchwangan- } \\
\text { ghass }\end{array}$ & July-September & Diarrhoea & $\begin{array}{l}\text { Whole } \\
\text { plant }\end{array}$ & $\begin{array}{l}\text { Decoction of whole plant is } \\
\text { given to treat diarrhea. }\end{array}$ & Oral & Wild \\
\hline 10 & $\begin{array}{l}\text { Physalis alkekengi L. } \\
\text { Solanaceae }\end{array}$ & Kaknaj & July-August & Kidney stone & Fruit & $\begin{array}{l}\text { Decoction of fruit is used to } \\
\text { remove kidney stone. }\end{array}$ & Oral & Cultivated \\
\hline 11 & $\begin{array}{l}\text { Polygonum alpinum All. } \\
\text { Polygonaceae }\end{array}$ & Masloon & June-July & Diarrhea & Seed & $\begin{array}{l}\text { Infusion of seeds is taken in } \\
\text { diarrhea }\end{array}$ & Oral & Wild \\
\hline 12 & $\begin{array}{l}\text { Polygonum aviculare L. } \\
\text { Polygonaceae }\end{array}$ & Dudijj & July-October & Boils & Leaves & $\begin{array}{l}\text { Paste of leaves is applied on } \\
\text { boils for quick healing. }\end{array}$ & Topical & Wild \\
\hline 13 & $\begin{array}{l}\text { Rheum emodi Wall.ex.Meisn. } \\
\text { Polygonaceae }\end{array}$ & Pam-tsalan & June-July & Boils, Ulcers & Rhizome & $\begin{array}{l}\text { Paste of rhizome is applied for } \\
\text { boils and ulcers }\end{array}$ & Topical & Wild \\
\hline 14 & $\begin{array}{l}\text { Rheum webbianum Royle. } \\
\text { Polygonaceae }\end{array}$ & Pamb-haakh & June-July & Body weakness & Rhizome & $\begin{array}{l}\text { Powder of rhizome is taken } \\
\text { as tonic for general body } \\
\text { weakness. }\end{array}$ & Oral & Wild \\
\hline 15 & $\begin{array}{l}\text { Rumex patientia L. } \\
\text { Polygonaceae }\end{array}$ & Jangli-abij & June-July & Itching & Root & $\begin{array}{l}\text { Root heated in mustard oil } \\
\text { is used as poultice to relieve } \\
\text { itching of skin. }\end{array}$ & Topical & Wild \\
\hline 16 & $\begin{array}{l}\text { Rumex acetosa L. } \\
\text { Polygonaceae }\end{array}$ & Bardana & May-June & $\begin{array}{l}\text { Abdominal } \\
\text { pain. }\end{array}$ & leaves & $\begin{array}{l}\text { Leaves of the plant are } \\
\text { cooked as vegetable and taken } \\
\text { against abdominal pain. }\end{array}$ & Oral & Wild \\
\hline 17 & $\begin{array}{l}\text { Rumex acetosella L. } \\
\text { Polygonaceae }\end{array}$ & Abij & June-August & Cough, Fever & Leaves & $\begin{array}{l}\text { Decoction of leaves is taken to } \\
\text { treat fever and cough. }\end{array}$ & Oral & Wild \\
\hline 18 & $\begin{array}{l}\text { Rumex dentatus } L \text {. } \\
\text { Polygonaceae }\end{array}$ & Abij & May-June & $\begin{array}{l}\text { Constipation } \\
\text {,Body } \\
\text { weakness }\end{array}$ & root & $\begin{array}{l}\text { Extract of root is taken with } \\
\text { water to cure Constipation } \\
\text { and general body weakness. }\end{array}$ & Oral & Wild \\
\hline 19 & $\begin{array}{l}\text { Rumex hestatus D.Don } \\
\text { Polygonaceae }\end{array}$ & Abij & June-October & Acne & Stem & $\begin{array}{l}\text { Juice of stem is applied to } \\
\text { treat acne. }\end{array}$ & Topical & Wild \\
\hline 20 & $\begin{array}{l}\text { Rumex nepalensis Spreng. } \\
\text { Polygonaceae }\end{array}$ & Jungle-palak & $\begin{array}{l}\text { August- } \\
\text { September }\end{array}$ & Stomach pain & Root & $\begin{array}{l}\text { Decoction of root is used to } \\
\text { cure stomach pain. }\end{array}$ & Oral & Wild \\
\hline 21 & $\begin{array}{l}\text { Solanum lycopersicum L. } \\
\text { Solanaceae }\end{array}$ & Tamatar & June-September & Ringworms & Leaf & $\begin{array}{l}\text { Leaf juice is applied to cure } \\
\text { ringworms. }\end{array}$ & Topical & Cultivated \\
\hline 22 & $\begin{array}{l}\text { Solanum melongena } \mathrm{L} \text {. } \\
\text { Solanaceae }\end{array}$ & Wangun & June-September & Asthma & Leaves & $\begin{array}{l}\text { Extract of leaves is useful in } \\
\text { Asthma and bronchitis. }\end{array}$ & Oral & Cultivated \\
\hline 23 & $\begin{array}{l}\text { Solanum nigrum L. } \\
\text { Solanaceae }\end{array}$ & Kambai & June-October & $\begin{array}{l}\text { Burns, Skin } \\
\text { disease }\end{array}$ & Fruit & $\begin{array}{l}\text { Paste of leaves is applied } \\
\text { directly on burns and skin } \\
\text { disorders. }\end{array}$ & Topical & Wild \\
\hline 24 & $\begin{array}{l}\text { Solanum surrantense } \\
\text { Burm. } \\
\text { Solanaceae }\end{array}$ & $\begin{array}{l}\text { Hoon- } \\
\text { hendwand }\end{array}$ & May-November & $\begin{array}{l}\text { Abdominal } \\
\text { pain, Gastric } \\
\text { problems }\end{array}$ & Fruit & $\begin{array}{l}\text { Dried fruit powder is taken } \\
\text { to cure abdominal pain and } \\
\text { gastric problems. }\end{array}$ & Oral & Wild \\
\hline 25 & $\begin{array}{l}\text { Solanum tuberosum L. } \\
\text { Solanaceae }\end{array}$ & Alua & March-April & $\begin{array}{l}\text { Headache, } \\
\text { Burns }\end{array}$ & Tuber & $\begin{array}{l}\text { Paste of the tuber is applied } \\
\text { topically on forehead to } \\
\text { relieve headache and used as } \\
\text { plaster for burns. }\end{array}$ & Topical & Cultivated \\
\hline
\end{tabular}




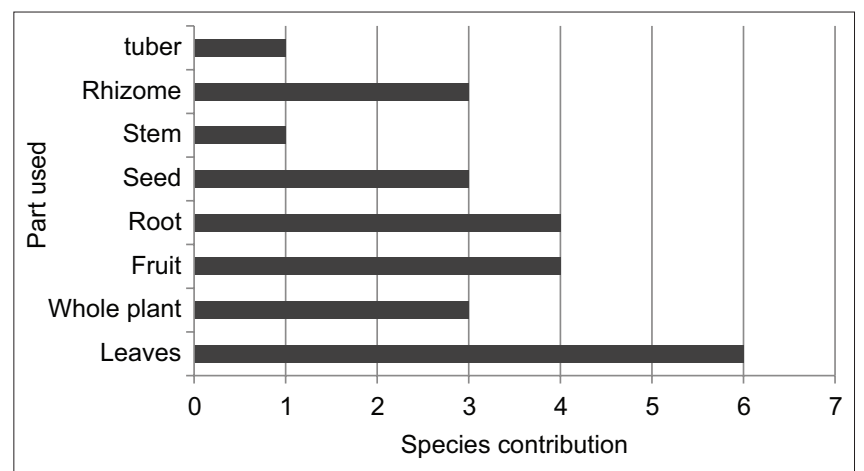

Figure 3: Different plant parts used with species contribution.

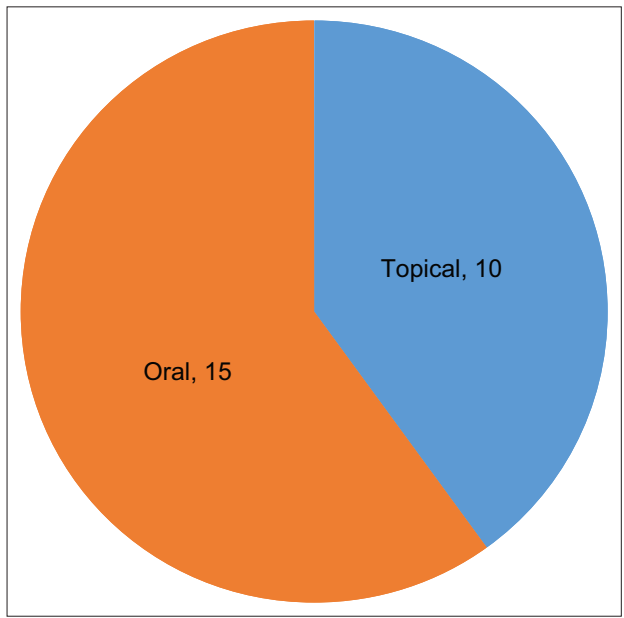

Figure 4: Mode of application of herbal remedy.

now only confined to old age folks only as new generation is not so keen to keep this knowledge with them due to their modern lifestyle and this knowledge is on the verge of extinction. Our study will provide a database of plants belonging to family Solanaceae and Polygonaceae being used for the treatment of different ailments and will work towards the conservation of locally available valuable knowledge regarding these plants.

\section{CONCLUSION}

Medicinal plants are the backbone of traditional health care system as it is the primary health care facility being used by most of the people around the world. Medicinal plants are not only used in developing countries but they are making their popularity in industrialised countries as well because of their negligible side effects and cost effective condition. But due to urbanization and modernization this asset is on the verge of extinction. So there is dire need to conserve it before it will get vanished. Therefore documentation of the plants provides a way towards the conservation of this valuable resource.

\section{REFERENCES}

1. Kar A, Barthakur SK. Medicinal Plants used against dysentery, diarrhoea and cholera by the tribes of erstwhile Kameng district of Arunachal Pradesh. Natural Product Radiance, 2008; 7: 176-181.

2. Prajapati ND, Purohit SS, Sharma AK, Kumar T. A handbook of medicinal plants. Agrobios, Jodhpur. India, 2003.

3. Ahmed SS. Medicinal wild plants from Lahore Islamabad Motor way (M-2) Pakistan. Pakistan Journal of Botany, 2007; 39: 355-375.

4. World Health organization (WHO) Traditional medicine fact sheet. 2003; 134.

5. Kala CP, Pitamber PD, Sajwan BS. Developing the medicinal plants sector in northern India: Challenges and opportunities. Journal of Ethnobiology and Ethno-medicine, 2006; 2: 32.

6. Ignacimuthu I, Ayyanar M, Sivaraman S. Ethnomedicinal investigations among tribes in Madurai District of Tamil Nadu (India). Journal of Ethnobiology and Ethno-medicine, 2006; 2: 25.

7. Kala CP. Ethno-medicinal botany of the Apatani in the Eastern Himalayan region of India. Journal of Ethnobiology and Ethnomedicine, 2005; $1: 11$.

8. Mitalaya KD, Bhatt DC, Patel NK, Didia SK. Herbal remedies used for hair disorders by tribals and rural folk in Gujarat. Indian Journal of Traditional Knowledge, 2003; 2(4): 43-65.

9. Brahman M. Indigenous Medicinal plants for modern drug development programme: Revitalization of Native Health Tradition: Advances of Plant Sciences, 2000; 1391: 1-10.

10. Awadh A, Ali N, Al-Rahwi IK, Lindequist U. Some medicinal plants used in Yemeni herbal medicine to treat malaria. African Journal of Traditional, Complemetary and Alternative Medicines, 2004; 1: 72-76.

11. O'Neill AR, Badola HK, Dhyani PP, Rana SK. Integrating ethno-biological knowledge into biodiversity conservation in the Eastern Himalayas. Journal of Ethnobotany and Ethno-medicine, 2017; 13: 21.

12. IDSP. Weekly Outbreaks. http://www.idsp.nic.in JGK Forest Department. 2018. http://jkforest.gov.in/geo_area.html

13. Shah A, Bharati KA, Ahmad J, Sharma MP. New ethnomedicinal claims from Gujjar and Bakerwals tribes of Rajouri and Poonch districts of Jammu and Kashmir, India. Journal of Ethnopharmacology, 2015; 166: 119-128.

14. Rajadurai M, Vidhya VG, Ramya M, Bhaskar A. Ethno-medicinal plants used by the traditional healers of Pachamalai hill, Tamilnadu, India. Ethnomedicine, 2009; 3(1): 39-41.

15. Miller AG, Nyberg JA. Collecting Herbarium Vouchers. (Royal Botanic Garden, Edinburgh EH3 5LR, U.K), 1995; 561-573.

16. Singh NP, Singh DK, Uniyal BP. Flora of Jammu \& Kashmir: Pteridophytes Gymnosperms and Angiosperms, Vol 1, Botanical Survey of India, New Delhi, India, 2002.

17. Hooker JD. The Flora of British India, Vol 2. (L. Reeve and Co., Ashford, Kent, England), 1879, 78-99.

18. Navchoo IA, Kachroo P. Flora of Pulwama, Kashmir, Bishen Singh and Mahendra Pal Singh, Dehradun, 1995.

19. Singh JB, Kachroo P. Forest Flora of Pir Panjal Range: North Western Himalaya, Bishen Singh Mahendra Pal Singh, Dehradun, India, 1994.

20. Anzar AA, Rashid I, Reshi Z, Dar GH, Wafai BA. The Alien Flora of Kashmir Himalaya. Biological Invasions, 2007; 9: 262 - 292.

21. Rai LK, Prasad P, Sharma E. Conservation threats to some important plants of the Sikkim Himalaya, Biological Conservation, 2000; 93: $27-33$. 